\title{
23 A Global Player? Transatlantic Shakespeare as an Example of Cultural Circulation Processes
}

\begin{abstract}
This contribution examines how Shakespeare's plays enabled various processes of cultural circulation, which could be described as transatlantic. Thus, this chapter does not provide an historical overview on Shakespeare appropriations in North America; it rather focuses on selected phenomena in order to capture the variety of cultural mobilities. Not only does this chapter focus on Shakespeare in performance, literature, on screen and in popular culture, it also reveals Shakespeare as a global player, while understanding 'transatlantic' as one aspect of the global. The entanglement of methodological reflection and punctual analysis opens the spectrum to consider processes of circulation beyond the framework of postcolonial investigations and therefore is to be located within reflections on cultural mobility studies.
\end{abstract}

Key Terms: Cultural circulation, performance, musical, Wooster Group, YouTube

\section{1 'Transatlantic' as Cultural Circulation}

When thinking about the transatlantic relationship between Europe and North America in connection to Shakespeare, many examples of performance, film, literature and popular culture can be found. For instance, Laurence Olivier's Hamlet (1948) is not only a major English film adaptation of Shakespeare's tragedy, but is also the first European film to win the Academy Award for 'Best Picture.' Is it a coincidence that a Shakespeare film won this award? Or, in other words: What role does Shakespeare play in this nomination? Is this an example of 'transatlantic Shakespeare'? And what do we mean with the term 'transatlantic'?

In recent years, the number of academic studies dealing with concepts of global circulation has increased. This chapter will argue that 'transatlantic' can be understood as one of the categories that describes the dynamic processes of on-going cultural circulation. Through the lens of 'transatlantic,' processes of cultural appropriation can be considered beyond a binary model of colonial expansion. When reflecting on global circulation, 'transatlantic' can be understood as a particular aspect of global circulation processes, with its particularity resulting from a geographical and linguistic constraint, namely explicitly focussing on English-speaking North America and Great Britain. In this context, Shakespeare is understood as a common ground for 
cultural analysis that enables and enforces various processes of circulation. Related to these assumptions, the following questions will be posed: What is it exactly that is circulating, and under what specific conditions does it circulate? Furthermore, what are the effects of these circulation processes?

The first methodological approach that is crucial to this chapter is Stephen Greenblatt's 'cultural mobility.' According to Greenblatt, mobility must be taken in a literal sense, namely in the sense of movement. This movement can include persons and cultural goods, as well as the infrastructural and institutional conditions of movement. Therefore, every study of mobility should shed light on the particular conditions of movement and of certain contact zones in which cultural goods are exchanged (Greenblatt 2010, 251-252). By understanding Shakespeare as a basis for Britain's and North America's processes of cultural circulation, we have to shed light on the factors that are circulating (e.g., travelling troupes, technology, topics), and also the specific effects of these processes and how they impact a certain cultural self-understanding.

Similar to Greenblatt, Alexa Huang's reflection on 'Global Shakespeare' highlights the tension between local cultures and global phenomena. In analysing various transnational projects, like the "Globe-to-Globe" Festival during the Olympic Games in London in 2012, Huang discusses the specific condition of Shakespeare becoming a transnational brand. As many performances and other cultural productions seem to work against assumptions of politically defined geographies, she reads the notion of 'Global Shakespeare' as a chance to shed light on "liminality, archival silence, Shakespeare in diaspora” and to move away from the colonial framework of post-colonial investigations (Huang 2013, 287). Therefore, the focus on moving cultural objects and their economic, political, and cultural conditions allows the definition of processes of cultural appropriation as dynamic and beyond the restrictive concept of national appropriation. In this sense 'transatlantic Shakespeare' means the mobility of certain topics that enforce various cultural questions (e.g., cultural identity, class belonging, typecasting), techniques and cultural practices that have an impact on aesthetics. In reference to Marjorie Garber's understanding of Shakespeare being inherently modern (Garber 2008), 'transatlantic Shakespeare' could be understood as a certain framework for thinking, and therefore as a common language. Furthermore, by understanding Shakespeare as a transnational brand, his reception history emerges as a shared system of references, which provides a common language as well as a system of comparison. Shakespeare, therefore, is a common ground for comparison that enables various and interrelating cultural phenomena. Through a timely and select analysis, 'transatlantic Shakespeare' not only allows an alternative perspective on historical processes (= cultural history), but also offers a common ground to bring different cultural phenomena into a comparative perspective (= cultural history, cultural analysis and aesthetics).

By comprehending 'transatlantic Shakespeare' in this way, this paper does not aim to give an overview of cultural appropriations of Shakespeare in North America. There are already very important and substantial studies - such as Kim C. Sturgess' 
Shakespeare and the American Nation (2004), Alden T. and Virginia Mason Vaughan's Shakespeare in America (2012), Frances Teague's Shakespeare and the American Popular Stage (2006), Ric Knowles' Shakespeare and Canada (2004), Susan Knutson's Canadian Shakespeare (2010), etc. - and another essay would only provide an abridged perspective of the history of Shakespeare in North America. Rather, this chapter explicitly focuses on selected processes of cultural circulation that have an impact on cultural history or particular aesthetics on both sides of the Atlantic Ocean. The aim is to open up the spectrum of various processes and types of circulation that could be subsumed under the concept of the transatlantic. This chapter concentrates primarily on the United States of America and will make a few references to Canadian performances and festivals. It is structured into five sections: the first section offers a historical perspective on early mobilities, while the following sections provide analysis of 'transatlantic Shakespeare' in performance, on screen, in literature and popular culture. The effects of these circulations are the negotiation of cultural identity, nation-building, class belonging and aesthetics.

\section{Early Mobilities}

This section will consider the specific conditions of circulating books and travelling troupes in North America that had an impact on the reception of the bard in what would eventually become the United States. The title 'early mobilities' refers to multiple circulation processes and therefore addresses various cultural phenomena. Even though many Americans did express anti-English sentiment in the years before and after the revolution in 1776, Shakespeare nevertheless remained popular in North America (Sturgess 2004, 24). Sturgess analyses the impact of Shakespeare's popularity on America's stages and provides an insight into various strategies since the eighteenth century to legitimise Shakespeare as part of American culture. He focuses on various national imaginaries - constructing the American Nation out of the AngloSaxon myth, differentiating English from British culture (Sturgess 2004, 25) - and provides an overview of these strategies and cultural events.

A prime example of the adoption of Shakespeare into American culture is John Adams' - the second president of the United States - and Thomas Jefferson's visit in Stratford-upon-Avon in 1786. Both reported how Americans valued Shakespeare more than the English. This notion could be read as a first step in a particular direction: Shakespeare was not only circulating in the context of arts and literature, he was also circulating within various political discourses. Thus, he played a central role in various political speeches in the nineteenth century, especially the speeches on 4 July (Sturgess 2004, 30). During the nineteenth century, Shakespeare became a crucial figure for the American national imaginary, despite the fact that he originated from the former coloniser. Shakespeare's history plays in particular provided many narra- 
tives against English tyranny. Richard III was Shakespeare's most popular play in the eighteenth and nineteenth centuries and was also the first Shakespearean play staged in what would eventually become the United States, namely in New York by the 'Murray-Kean Company' in 1750 (Teague 2006, 17-18).

Early print editions and travelling troupes, both of which affected Shakespeare's popularity in North America, will be considered in relation to the main question: what is circulating and under what conditions? Even though Shakespeare was not present on American stages until the second quarter of the eighteenth century - there were non-professional performances before 1750 - he was clearly present in the form of books. The first editions of Shakespeare's work in North America were imported from English publishers - such as Nicholas Rowe's edition from 1709 - which made Shakespeare more available in North America (Teague 2006, 16). Another admired edition was Samuel Johnson's and George Stevens' comprehensive ten-volume English edition from 1773 (Vaughan 2012, 51). Due to the absence of copyright protection ( $\pi 22$ The Transatlantic Publishing Industry), these editions could be freely reprinted in North America and hence be 'Americanised' at the same time. For instance, some American publishers distributed Shakespeare's plays using the same edition but changed the preface in order to celebrate American national superiority over England (Vaughan 2012, 51-55), such as in Joseph Hopkinson's edition from July 1795 (Sturgess 2004, 60).

Even though these English editions were travelling in both cultural contexts, these circulation processes had more of an effect on the internal American mobility than any transatlantic one. During America's political and cultural westward expansion in the nineteenth century, the supremacy of the Anglo-Saxon myth was significant in legitimising geopolitical extension. Shakespeare was an admired source of a future shared national language and could be considered as a reference for American culture (Sturgess 2004, 102-118). The distribution of his works throughout the territory of the United States is also reflected in various travel journals by European authors, such as Alexis de Tocqueville's remark on Shakespeare's popularity in the New World during his visit to the United States: “There is hardly a pioneer's hut which does not contain a few odd volumes of Shak[e]spe[a]re. I remember that I read the feudal play of Henry V. for the first time in a log house" (de Tocqueville 1840, 57; Sturgess 2004, 34-46). Even though these processes can be considered as aspects of an inter-American circulation, this example reveals how processes of circulation were recognised and received in Europe (Sturgess 2004, 43-47).

The mobility of these editions as well as the revival of Shakespeare in Georgian Britain influenced the reception of Shakespeare on New England's stages. Thus, another important aspect of so-called early mobilities are the travelling, mostly English troupes performing Shakespeare on American stages. Although there are no Shakespearean performances listed in the years of early settlement, between 1750 and 1776 around 500 performances of Shakespeare were staged (Teague 2006, 15-18) and, despite the political tensions between the royalists and the revolutionists, Shakespeare served both sides of the political conflict well. According to Teague, the Theatre 
Licensing Act in England in 1737 forced many English theatre companies to migrate to North America in order to earn a living (Teague 2006, 18). Political decisions in England clearly influenced the work of travelling troupes by forcing their circulation. In this context the 'Hallam-Troupe' should be mentioned, who first performed under the name of the 'London Company of Comedians.' After the change of their principal actor the company was renamed the 'Douglass Company' and became the 'American Company' in 1763 (Vaughan 2012, 17). Early performances of Shakespeare varied from each other in different regions: in New England, Shakespeare was presented as so-called moral dialogues by the 'Douglass Company' to the local audiences in 1761 (Teague 2006, 19), and there were also Shakespeare adaptations, such as The Tempest, rewritten by Sir William Davenant and John Dryden in 1667, and later readapted as an opera by Thomas Shadwell in 1674 with music mostly by Matthew Locke (Vaughan 2012, 24-25). These early American theatre activities were clearly influenced by circulating troupes, where Shakespeare provided a well-known system of references that addressed both cultural contexts. Even though Shakespeare on stage was largely associated with British cultural practice during the years of revolution, different companies continued to show Shakespeare for commercial purposes, such as the 'Maryland Company.' Nevertheless, we should take into account that during the Revolution attending a play was limited in revolution areas (Teague 2006, 22).

After the revolution New York and Charleston became America's theatrical centres. Due to the perceived neutrality of Shakespeare's work during the revolution, Shakespeare continued to be part of America's theatrical culture. The 'American Company' returned to New York after performing in Jamaica during the revolutionary years. New theatres were opened, such as Philadelphia's Chestnut Street Theatre, Boston's Federal Street Theatre and New York's Park Theatre (Vaughan 2012, 37-38). Many English actors also came across the Atlantic and performed, such as James Fennel who played in Philadelphia in 1793 (Vaughan 2012, 28). The circulation of these actors and editions established a theatrical repertory in America that marks Shakespeare as a popular system of reference. As we will see later, the circulation of actors functions also the other way round, for example in reference to the African American actor Ira Aldridge, who immigrated to England.

In the case of Canada, various performances by amateurs - such as soldiers - and professional actors first date from the eighteenth century (Brydon and Makaryk 2002, 9). The first professional British company that settled in Canada was Edward Allen's 'Company of Comedians' in 1786. In these early years of Canadian theatre, many actors and troupes circulated from England to Canada, and also via what would later become the United States. In the nineteenth century, most theatrical venues were established in centres such as Montreal, Toronto and Winnipeg, and brought prominent English actors to Canada such as Edmund Kean (Brydon and Makaryk 2002, 12), who also travelled through the United States (Vaughan 2012, 41). Thus, similar to the United States, circulating actors and troupes influenced the reception of Shakespeare in what is today Canada. 
Shakespeare's popularity becomes visible in the circulation of various cultural goods: during British rule, the cult of Shakespeare was mirrored in domestic furnishings such as in busts of Shakespeare or even chess figures with characters of his plays (Teague 2006, 23); while after the revolution, Shakespeare calendars (Sturgess 2004) and Shakespeare statues could be found across the United States. A prominent example is the statue in Central Park New York, which was installed in 1872 (Sturgess 2004, 126-127). This later aspect could be called 'symbolic geography,' which becomes strikingly visible in the location of the Folger Shakespeare Library on Capitol Hill in Washington, D.C., which was opened in 1932 and is physically located at the heart of American politics. Thus, 'symbolic geography' describes a specific relationship between space, power and identity. The library’s founder was Henry Clay Folger, who collected Shakespearean editions and worked together with his wife Emily Clara Jordan, a Shakespeare scholar, on various editions. This library holds the world's largest collection of First Folios from 1623, with 82 specimens (Vaughan 2012, 137). This institution not only affected American Shakespeare scholarship, such as Esther Cloudman Dunn's first examination of Shakespeare in America in 1939 (Teague 2012, 719), but also international scholarship across the Atlantic. For example, the Folger Library produced journal Shakespeare Quarterly is one of the leading journals in Shakespeare scholarship. Therefore, the circulation of Shakespearean sources and editions encouraged international scholarship that provides another perspective on transatlantic Shakespeare.

\section{Circulating Shakespeare on North American Stages}

Although Shakespeare was not often performed at the beginning of English settlement, the spectrum of Shakespeare performances in North America grew during the nineteenth century. Over this period, a distinction between legitimate, in the sense of high-cultural, and variety entertainment was drawn in North America (Teague 2006, 79-80): While Shakespeare's plays remained in the repertoire of major theatres, other forms of entertainment such as vaudeville, burlesque and minstrels included Shakespeare in their shows. His characters and scenes often worked as a catalyst for mocking ethnicity and gender (Teague 2006, 86). As vaudeville became one of the most popular middle-class entertainments, its use of Shakespeare turned the English writer into an aesthetic marker of difference between both forms of cultural entertainment, and therefore became a platform to negotiate various cultural questions, such as those concerning social class. The possibility to appropriate Shakespeare within various genres and artistic formats exemplifies his dramatic form as approachable for various cultural contexts and as able to provide a certain agency. This section asks how cultural mobility can be described in relation to the multiple formats of Shake- 
speare in performances, which were also reflected across the Atlantic. Therefore, we will consider how processes of circulation become visible within performances. At the same time, this section will look at performances, styles and genres circulating across the Atlantic, providing an overview of both Shakespeare on North American stages and certain aspects of mobility that can be considered 'transatlantic.'

The first example is the Astor Place Riot of 1849, which shows how circulating actors from both sides of the Atlantic provoke a phenomenon that could be considered a 'transatlantic rivalry.' This particular event was the peak of a dispute between two Shakespearean actors, the English actor William Macready and the well-known American actor Edwin Forrest. Both actors enjoyed a friendly relationship and travelled back and forth between the United States and England. On their international tours they performed in a repertory of mostly Shakespearean plays. When Forrest received a bad critique in England during his second visit, he blamed Macready for contributing to those negative articles. He decided to stir up riots during Macready's third American tour in 1848 and 1849. These tensions became clear when, during his visit, Forrest determined to act in the same roles as Macready. Macready's tour was meant to end in New York where he was playing Macbeth at the Astor Place Opera House on 7 May 1849. This theatre was associated with the upper class because it was much more expensive and was situated in a very elite area in New York (Teague 2006, 55-63). Even though a small riot had already happened during the performance of the 7 May, Macready decided to return and to act Macbeth again on 10 May. This decision led to a huge riot involving 10-15,000 working-class people demonstrating in front of the Astor Place Theatre. Even though the event was accompanied by various public contributions from both actors in different newspapers, the aesthetic dispute about performances of Shakespeare worked as a catalyst for the collision of cultural, national and class interests (Teague 2006, 61-63; Vaughan 2012, 35-43). These riots were an expression of the growing tension between immigrants and the so-called natives who had established the Know-Nothing party before American Civil War (Teague 2006, 64). Thus, the issue of whether Shakespeare needed to be shown in front of particular audiences arose, and as a consequence, the question who was authorised to play Shakespeare in American theatres. This event is an instance of 'transatlantic rivalry,' and from a cultural-historical perspective, exemplifies how Shakespeare played a crucial role in the national imaginary of the second half of the nineteenth century. The mobility of Shakespearean actors and the presence of various reviews meant that a Shakespearean performance became a platform to negotiate cultural identity and class issues.

Although Shakespeare was a stable part of the American imaginary in the nineteenth and early twentieth centuries, because of the racial politics of the United States in this period hardly any African American actors played on the established stages of North America. An exception to this is the 'African Company,' which was founded by West Indian immigrant William Henry Brown in 1821. This first Afro-American theatre company regularly staged Shakespeare and their first performance was Richard III 
(Vaughan 2012, 113; Hornback 2010). Due to the company's success, they moved from the African Grove Tea Garden to a larger theatre on Mercer Street in New York. The combination of a black cast - with James Hewlett as one of the first African American actors - and black management made their repertory a provocation to other theatre directors, such as Stephen Price of the New York's Park Theatre (Vaughan 2012, 113). The company chose to play Shakespeare not merely as entertainment but to also demonstrate that African Americans were not inferior to white Americans (Hornback 2010, 130). Due to these tensions the company was forced by the police to shut down after three years of work and only sporadically performed their Shakespearean repertory until 1843 (Hornback 2010, 129). Furthermore, they were officially prohibited to perform Shakespeare on legitimate American stages. Thus, by the end of the 1820s there was no formal venue for African American actors. They were either forced to perform in variety performances or to migrate to Europe, as did the well-known member of the African Company, Ira Aldridge (Vaughan 2012, 113; Lindfors 2013). He and other actors of the company left for Europe where they found an audience for their Shakespeare performances (Hill 1984, 19; Vaughan 2012, 113-114). This forced process of circulation significantly influenced the debate and reflection on typecasting and ethnicity on stage on both sides of the Atlantic and across different theatrical genres. Thus, it was Ira Aldridge who performed as the first black Othello in Covent Garden in London in 1833 (Lindfors 2007). Shakespeare here provided a shared artistic language and repertory that enabled their performances.

At the same time, his performance, as well as the performances of other African American actors like James Hewlett, were parodied in minstrel shows, mocking through visual representation as well as the so-called 'black language.' According to Hornback, Shakespearean language was valued as background for mockery in minstrel shows on both sides of the Atlantic (Hornback 2010). Thus, minstrelsy, which originated in the United States, circulated to Europe, where it became a form of popular entertainment (Young 2014). By analysing the events around the 'African Company,' it becomes clear as to how Shakespeare reflected the status of African American community within a dominant Anglo-American culture at the beginning of the nineteenth century. The fact that African actors were not present on regular performance stages exemplifies the interrelation of aesthetics and cultural history. Even though the opportunities for African American actors to perform on stages changed during the third decade of the twentieth century, it was not until 1943 that an African American actor, namely Paul Robeson, played Othello with an Anglo-American cast (Vaughan 2012, 118).

In the tradition of musical comedy on North American stages, Shakespeare musicals provide a special and very popular form of entertainment. Even though this genre does not refer to Shakespeare's language in the sense of the written text, the main situations and story lines were interpreted through music, songs and dance (Vaughan 2012, 168). Frances Teague, in her book Shakespeare and the American Popular Stage (2006), conducts a cultural-historical examination of the Shakespeare Musical genre 
and mentions the musical comedy Mr. Hamlet of Broadway (1908) by Eddie Foy as one of the first musical comedies referring to Shakespeare (Teague 2006, 109). The first Shakespearean book musical is Lorenz Hart's and Richard Rodger's The Boys from Syracuse, which opened at New York's Alvin Theatre in November 1938 (Vaughan 2012, 168). According to Teague, this book musical is less burlesque, borrowing characters and stories from The Comedy of Errors and does not mock Shakespeare's tragedies. Furthermore, The Boys from Syracuse alludes to other Shakespearean plays such as A Midsummer Night's Dream, Julius Caesar and Twelfth Night (Teague 2006, 111-115). Soon after the successful performance of Shakespeare's first book musical another production opened in November 1939. Swingin' the Dream premiered at New York's Centre Theatre, and alluded to A Midsummer Night's Dream and incorporated African American swing music. According to Vaughan, various popular African American performers were involved and well-known swing numbers, for example by Benny Goodman, were included (Vaughan 2012, 169; Teague 2006, 128).

Soon after these events, two very successful and well-known productions were staged. The first one was Kiss Me, Kate, which premiered on Broadway in 1948 and won twelve Tony awards (Vaughan 2012, 169; Teague 2006, 122-142). This book musical refers in multiple ways to Shakespeare's The Taming of the Shrew and combines songs by Cole Porter with a choreography by Hanya Holme and a book by Bella Spewak (Vaughan 2012, 169). The first Shakespearean tragedy to be adapted in the genre was Romeo and Juliet in West Side Story, which opened in 1957 in Washington, D. C. This very successful production combined lyrics by Stephen Sondheim, a book by Arthur Laurent and music by Leonard Bernstein, adapting the tragedy to the rivalry of Puerto Rican and Anglo-American street gangs. In 1961 the musical was adapted into a motion picture and won ten Academy Awards (Vaughan 2012, 171; Teague 2006, 142). Even though other musicals referring to Shakespeare in North American popular entertainment can be found, we have to ask why this phenomenon could be described as an instance of the 'transatlantic Shakespeare.' Focussing on processes of cultural circulation, we can find two aspects of cultural mobility: first, we have Shakespearean plays and their characters being appropriated within legitimate and variety performances on North American stages. Second, we have musicals referring to Shakespeare, which become a major form of popular entertainment in America and Europe. This double process of circulation transmits travelling stories and characters into a new genre and into different cultural contexts.

Another aspect of cultural circulation and performance is the movement of certain architectures and techniques, which were imported from Europe and influenced American cultural practice. In order to analyse these aspects we have to take into account tourist venues and Shakespeare festivals that not only refer to a certain style of performance, but also bring national and international audiences to North America every year. In the United States, over two hundred Shakespeare Festivals can be found (Vaughan 2012, 192). According to Lanier, these festivals aim to celebrate a so-called authentic Shakespeare experience and therefore present classic performances allud- 
ing to Early Modern staging practice rather than contemporary approaches to Shakespeare's plays. Typically, these festivals produce a certain Renaissance fair and show their plays in reconstructions of the Globe or Blackfriars Theatres. Here are only a few examples to give an impression of the variety of these festivals: the Oregon Shakespeare Festival, which is based in Ashland Ontario (Vaughan 2012, 177); the New York Shakespeare Festival, which is now called the Public Theatre (Lanier 2002, 156); the Shakespeare Festival of Dallas; the Utah Shakespearean Festival and the Virginia Shakespeare Festival. In addition there are also younger festivals such as the Harlem Shakespeare Festival.

Not only is the early modern architecture reconstructed in the United States, but also rehearsal and performance techniques are re-enacted. An example of a Shakespearean company taking an Early Modern approach is the 'American Shakespeare Center.' The ASC is a residence company founded in 1988 and based in Staunton, Virginia. The company, which has its own theatre, a reconstruction of the Blackfriars in London, not only provides a Renaissance location, but also devotes itself to a theatrical practice of the Early Modern period. Their so-called Renaissance Seasons (Ren Seasons) organise rehearsals as was done in Early Modern England. In these productions, the actors work without any director or other conventional team and only rehearse for a few days on a show. Since the actors are able to edit their own text, the performances are an on-going process of creation. According to Lenhardt, this Early Modern theatre practice provides another theatrical experience, not only for the actors but also for the audience (Lenhardt 2012). These festivals and productions stand in a long tradition of Shakespeare and tourism, which blossomed after the 1769 jubilee in England launched by the famous English Shakespeare actor David Garrick. The cultural circulation processes we are dealing with here are the circulation of certain techniques and approaches to Shakespeare. Even though so-called 'authentic Shakespeare' performances are influenced by a specific staging history clearly located in England, it also is more than a one-way circulation. It is striking that the world's first reconstruction of the Globe theatre was not in England but at the Chicago World's Fair in 1933, later relocated to Dallas (Texas) (Vaughan 2012, 151). Historicist reconstruction can be found also in Canada, such as the Anne Hathaway Cottage in Victoria British Columbia in 1959 and various Shakespeare theme parks (Vaughan 2012, 154). In this context it might be interesting to mention that the American actor, director and producer Sam Wanamaker initiated the reconstruction of the London Globe, which opened in 1997.

In Canada, Shakespeare festivals take on a major role in performing Shakespeare, such as the Shakespeare by the Sea Festival, the York Shakespeare Festival run by the Resurgence Theatre Company, the Shakespeare on the Saskatchewan Festival and Vancouver's Bard on the Beach (Ailles 2002). The Stratford Festival in Ontario, which was established in 1953, is one of the best-known and recognised institutions that has become an important meeting place for English and Canadian artists and emphasises transatlantic circulations of artists and productions. Within the context of post-war 
Canada and the liberation from British rule, the festival's British management came under criticism during the 1950s and 1960's, which also reflected national tendencies in Canada since the 1950's (Knowles 2004a, 31-35). The entanglement of Shakespeare with the institution enabled various circulations of artists and productions, while at the same time enforcing ideas of national identity and the question of an independent Canadian theatre culture (Knowles 2004a, 35-41).

At Shakespeare festivals the following circulation processes become visible: circulating theatrical techniques and architectures as well as circulating actors and directors. These processes affect the negotiation of cultural identity as exemplified in reference to Stratford, and also affect negotiations about a certain shared past, which could be read as an inscription into a staging and cultural history. But with respect to festivals, we come to another aspect of transatlantic: the circulation of certain productions across the Atlantic.

A good example is the collaborative work of the 'Wooster Group' and 'The Royal Shakespeare Company' for Troilus and Cressida (2012), which could be thought of as an aspect of travelling international or even 'transatlantic' aesthetics. This performance is an excellent example of transatlantic artistic cooperation in reference to Shakespeare. The production was part of the World Shakespeare Festival in London in 2012, and combined two different aesthetics since it was divided into two parts: while Elizabeth Le Compte directed and rehearsed the Trojans in New York, Mark Ravenhill worked with the RSC on the Greeks in England. Both parts premiered together in the Swan Theatre in Stratford-upon-Avon in 2012. In this production the American and English companies worked together and yet retained their own aesthetic manner, thus bringing questions about transatlantic approaches towards Shakespeare into focus (cf. Cartelli 2013; Fowler 2014). 'The Wooster Group' combined the Shakespearean text with various other media, such as Björk's music, the Native American Film Smoke Signals (1998), and the Inuit film Atanarjuat, or The Fast Runner (2001). Furthermore, they modified their language and spoke using a Northwestern Native American accent. Therefore, the Trojans playfully represented a 'stereotypical' Native American community, while bearing Greek statues on their back. In exposing the foreigner on stage, along with various strategies of 'othering,' the company made a particular Greek hegemonic worldview visible that became representative of Western society. Similar to their other performances, such as Hamlet (2007), the Wooster Group worked with gestures and images from film sources, which were projected on TV screens visible to the audience. Their intermedial acting style, significantly marked by the use of technology on stage (Mancewicz 2014, 86-96), and their references to Native Americans clearly differentiated them from the Greeks. Although Mark Ravenhill played with imperial stereotypes of the Greeks and therefore developed a critical take of the United Kingdom, compared to the Wooster Group's Trojans, the RSC's Greeks represented a particularly classical approach towards Shakespeare in the use of a certain psychologically realistic acting and a faithful approach towards the dramatic text. These differences in particular were reflected in various critics and 
reviews and ignited a discussion on how Shakespeare should be presented on stage (Fowler 2014). Therefore, this transatlantic cooperation not only revealed circulating actors and companies, but also circulating aesthetics, posing questions of who has the authority to revolutionise the approach to Shakespeare.

Other examples of circulating, 'transatlantic' Shakespeare performances are Robert Lepage's productions, such as his well-known rendering of A Midsummer Night's Dream (1992/1993) - controversial during its tour in the Royal National Theatre in London - and his bilingual production of Romeo and Juliet (1989/1990) (Paul 2007). According to Paul, these productions by the Canadian director focus on language in Shakespeare and therefore on shared boundaries in Canadian Shakespeare reception (Paul 2007, 46). A further example is his multimedia solo-performance of Elsinore (1996), which was performed in French and English and toured the international festival circuit (Knowles 2004b, 183).

These examples show the various circulation processes across the Atlantic that enable a certain framework of thinking about cultural identity, class belonging, a shared past and a particular aesthetic discourse. Even though this chapter can only highlight a few selected examples, it becomes clear that circulation processes affect many areas of Shakespeare in performance.

\section{Circulating Shakespeare's Characters and Storylines in North American Literature}

This section will begin with travelling characters and plots from Shakespeare's plays as intertextual references in North American literature, and consider how these mobile motifs enable Shakespeare to work as a framework for thinking about various cultural questions. Before returning to circulation processes we should reflect on Shakespeare as an important presence in American literature, as has been discussed in many publications (Engler 2003; Sturgess 2004). While such aspects play a marginal role in cultural circulation, nevertheless, there are key moments that need to be mentioned. In particular, after the American Revolutionary War 1776-1783, the political autonomy of the United States went hand-in-hand with a cultural independence (Engler 2003, 403). For American writers, Shakespeare could be seen as a pattern as well as reminding the young nation of the absence of its own literature. This contradiction was reflected in various poems from the United States following the American Revolutionary War (Engler 2003, 406). Even though Shakespeare was criticised in North America for lacking morals in his plays, and so had to be presented in the form of moral dialogues in New England, he was recognised as a major authority of English language and literature and thus had to be adapted to American culture. In order to get rid of his 'wrong' nationality, American authors proclaimed Shakespeare to be a universal genius whose nationality was inconsequential. To this end, various American poets 
used de-nationalising strategies in order to prove that Shakespeare's greatness was not related to British culture and life (Engler 2003, 410-413). Ralph Waldo Emerson, for example, in his lectures on Shakespeare in 1835, avoided explicit references to English culture and therefore introduced Shakespeare as a universal genius (Engler 2003, 414). While this reading suggests Shakespeare to be a supernatural, 'godlike' figure, other poets like Jones Very wanted to re-humanise Shakespeare. Very highlights in his essay Shakespeare (1838) that universality is characteristic of any human mind and therefore not specific to Shakespeare (Engler 2003, 414). In 1850, Emerson published his essay Shakespeare; or, the Poet in his collection Representative Men where he supported the original genius of a great man. Emerson's second essay can be read as a deconstruction of the romantic glorification of Shakespeare, taking him as an example for "the poet" (as the subtitle calls him). Besides Emerson, other American poets such as Herman Melville significantly contributed to the appropriation of Shakespeare into North American culture. While Melville identified Shakespeare with American business culture, other poets like Walt Whitman resisted appropriating Shakespeare without question and marked him as an ally to feudalism and therefore a poet of the upper class (Teague 2012, 726). The intellectual negotiation of the suitability of Shakespeare for American culture is an important premise for the intertextual circulation of Shakespeare's characters and plots in North American culture. We will now look at various characters and storylines of his plays that circulate in North American novels and dramas and provide a platform to negotiate cultural identity.

Intertextual references function as either a parody or homage to Shakespeare and can be understood as strategies of Americanisation. Upon closer examination of intertextual references to Hamlet, Mark Twain's novel Huckleberry Finn (1884) can be read as a parody of Shakespeare's well-known tragedy (Rippl 2014, 442). Aside from loose allusions to Shakespeare's plays, there are also extrapolations, such as Lillie Buffum Chace Wyman's Gertrude of Denmark: An Interpretive Romance (1924) - a prequel to Shakespeare's Hamlet that offers an interpretation of the female character. Wyman's book refers to Mary Cowden Clarke's Girlhoods of Shakespeare's Heroines (1850-1852) (Rippl 2014, 443). Bearing in mind that Wyman also refers to playful intertextualities in English Victorian literature, this doubled reference to Shakespeare's plays and his reception in England can be read as another phenomenon of 'transatlantic Shakespeare.' Clearly, both Shakespeare's plays and their reception were subject to processes of circulation. In order to critically investigate the dominant reception of Shakespeare, female writers like Gloria Naylor use the canonical author to express their feminist reflections (Rippl 2014, 443). Across various volumes Shakespeare becomes a platform to negotiate characters from his plays and a reflection of historical events, for example in Gary Lee Entsminger's and Susan Elizabeth Elliott's Ophelia's Ghost (2008) (Rippl 2014, 444). In addition to these intertextual references, there are examples where Shakespeare functions as an expression of a lifestyle, such as in Jess Winfield's My name is Will: A Novel of Sex, Drugs and Shakespeare (2008). 
Due to its complicated relationship to a colonial past as well as to the United States, independent Canadian national literature is doubly marginalised (Rippl 2014, 445). Nevertheless, authors use the subversive potential of Shakespeare in order to reflect on various cultural and historical topics, such as Margaret Laurence's The Diviners (1974), an extrapolation of The Tempest. There can also be found parodist feminist revisions of Hamlet like Margaret Atwood's Gertrude Talks Back (1992) and Sheila Watson's Brother Oedipus (1954) (Rippl 2014, 446). Even though the first impression of the transatlantic circulation of Shakespeare's characters and plots in North American literature predominantly suggests a unidirectional flow from England to North America, at the same time it shows how Shakespeare works as a framework for thinking about cultural and gender identity, particularly when considering the many novels and short stories that were also received in England, such as Mark Twain's novels (McParland 2014). Intertextual references to Shakespeare can be understood, therefore, as an expression of an on-going transatlantic circulation process between North America and Europe.

\section{Mobile Shakespeare on Screen}

In order to examine 'transatlantic Shakespeare' on screen, this section will focus on two aspects: how Shakespeare is related to early American and British film and how Shakespeare enabled transatlantic cooperation; therefore, 'Shakespeare on screen' needs to be understood as a phenomenon of global circulation processes (Teague 2006, 95).

The early film industry in particular used Shakespeare to establish movie making as an art form (Vaughan 2012, 160). In the United States, J. Stuart Blackton's Vitagraph Company adapted various Shakespeare plays as silent films, producing eleven of the most popular plays between 1908 and 1912 (Buchanan 2009). In this context, Shakespeare functioned as a provider of well-known stories that could be recognised by the audience. After the film industry's move to Hollywood, Columbia Pictures produced the Taming of the Shrew as a silent and spoken movie in 1929. Directed by Sam Taylor, the film unfortunately did not attract audiences. Nevertheless, Hollywood continued to produce films, such as A Midsummer Night's Dream, directed by Max Reinhardt in 1935 (Vaughan 2012, 165). These early full-length Shakespeare films did not attract broad film audiences; that would occur with Joseph L. Mankiewicz' Julius Caesar (1953). This production was a collaboration of American film and British stage actors - for example, Marlon Brando as Marc Antony and the British Shakespearean actor John Gielgud as Cassius - and was an epic film in Roman costumes on a historicist set (Vaughan 2012, 166; Taylor 2000, 266).

In early film production Shakespeare enabled various forms of circulation: Shakespeare was attractive material on both sides of the Atlantic and the mobility 
of Shakespearean stories and characters affected the new medium. There was also the circulation of European theatre artists and directors - whose individual careers were more or less connected to Shakespeare - through the United States, a movement that influenced the reception of Shakespeare on screen. When considering the film industry, another form of 'transatlantic rivalry' or 'competition' can be identified: the British film industry always had to cope with the dominance of Hollywood and therefore reacted to American Shakespearean movies with their own films, such as Hamlet (1996) and Love's Labour's Lost (2000) by English director and actor Kenneth Branagh. Similar to early performances in North America, the question of how Shakespeare must be 'depicted' was asked again in reference to film. This negotiation of the 'authentic representation of Shakespeare' on film is reflected in the movie production Looking for Richard (1996): Al Pacino complains about the problem of being an American actor and feeling inferior in reference to Shakespeare (Taylor 2000, 265).

Even though there are film versions of Shakespeare's plays between 1950 and 1990, this section focuses, in a second step, on productions in the decades after 1990, in which an increase of Shakespeare on screen becomes visible. Elsie Walker explores how Shakespeare on screen in English speaking countries either functions as a reflection of a certain past or as a playful template to reflect upon postmodern society (Walker 2006, 19-27). Michael Radford's The Merchant of Venice (2004) locates Shakespeare's plays in a romanticised past, whereas Baz Luhrman's William Shakespeare's Romeo+Juliet (1996) or Michael Almereyda's Hamlet (2000) refer to Shakespeare's timeless writing and adapt him within a postmodern context. According to Walker, in these postmodern adaptations the references to Shakespeare foreground the clash between Early Modern text and postmodern mise-en-scène by offering the viewer multiple perspectives on Shakespeare using materials from high and popular culture. In contrast to other classical movies, these films do not attempt to be original Shakespeare pieces, but 'authentic' as part of our post-modern culture (Walker 2006, 27). In this context Shakespeare is often used for figuring the global as a 'glocal' environment via references to local culture, which are foregrounded in a global, postmodern world (Burnett 2006, 141-148; Burnett 2012, 64). Thus, Shakespeare on screen is not only a global phenomenon in reference to production processes (e.g., transatlantic collaborations), but also on the level of content, a catalyst to reflect upon global circulation processes.

Taking a closer look at the reception of Shakespeare on screen, it is clear that American productions are better received in Europe than the other way around. Adaptations of Shakespeare to teen and high school themes in particular contribute to the success of American Shakespeare productions, such as Gil Junger's version of The Taming of the Shrew in 10 Things I hate about you! (1999), or Tim Blake Nelson's Othello adaptation “ $O$ ” (2001). But this is not true in reference to television productions: between 1949 and 1979 nearly fifty major Shakespeare productions produced by the Hallmark Hall of Fame were shown on television. Nevertheless, since 1979 most of the Shakespeare plays televised in the United States originate from England, 
produced by the BBC (Vaughan 2012, 175). While these classical TV productions of Shakespeare's plays are English productions, nowadays there are various American and Canadian TV series appropriating Shakespeare for a contemporary setting. The Canadian TV series Slings and Arrows (2003-2006) portrays the fictional New Burbage Festival, an allusion to the Canadian Stratford Festival, and refers on multiple levels to Hamlet and other Shakespearean tragedies. Not only does the setting resemble the Danish court through its changing power relations, the main character resembles Hamlet in the tradition of the modern romantic hero. He fights against the commercialisation of theatre and Shakespeare, and tries to protect them against the dreaded musical industry, which seems the only hope left for the festival to survive (Otto 2014, 504). Thus, in this series Shakespearean characters circulate into a new medium, while Shakespeare clearly functions as a platform to negotiate new aesthetics and the changing function of theatre in the twenty-first century. Another, very recent reading of Hamlet can be found in the American TV production The Royals (2015), in which the screenwriter Mark Schwahn loosely uses the play as a framework to reflect on a fictional English royal family. The series is an interrelation of Shakespeare as a provider of royal stories, such in his history plays and tragedies, and as global fascination, or better said, as the cult of contemporary European Royal families. Therefore, circulating knowledge about Shakespeare's Hamlet, located within a contemporary yellow-press context, uses him as a foil to negotiate global phenomena. Another important transatlantic TV production of Shakespeare's History Plays is “The Hollow Crown,” released by BBC and PBS in 2012. Similar to performance and literature, Shakespeare's characters and plots are circulating in various film and TV productions, either as adaptations within different historical and cultural contexts or as loose allusions in order to reflect upon various cultural questions.

\section{Circulating Shakespeare References in Popular Culture}

As already discussed in the sections above, Shakespeare is equally an aspect of high-cultural performances and popular entertainment. This section adds a further aspect, namely the analysis of multiple references to Shakespeare's plays in popular entertainment, which have to be understood as an inherently global phenomenon. This section deals with selected references in various television TV series, films, and internet phenomena, where Shakespeare works as a framework for thinking about media cultures (Otto 2014, 504).

With respect to the circulation of Shakespeare in various media and genres, it is not surprising that Shakespeare can be found in science fiction shows such as Star Trek. The character Captain Jean-Luc Picard (in the series Star Trek: The Next Generation as well as in the four movies developed from it) is played by the major Shake- 
spearean actor Patrick Stewart, and thus refers at a number of levels to Shakespeare. In Nicholas Meyer's film Star Trek VI: The Undiscovered Country (1991) there is even a major reference to Shakespeare's Hamlet. The Klingon chancellor Gorkon refers in multiple ways to Hamlet's soliloquy in Act III, Scene 1 during the diplomatic dinner. He alludes to him in his toast, and also offers a statement that becomes a crucial Shakespeare reference: "You've not experienced Shakespeare until you've read him in the original Klingon" (Lanier 2002, 2). This particular remark epitomises the fact that the discourse and reception around Shakespeare are stable parts of popular culture and its reflection. Furthermore, it emphasises in a playful way Shakespeare as a global, and in the universe of Star Trek even an interstellar, phenomena. Interestingly, this notion has led to actual translations of Hamlet into Klingon, for example by Lawrence Schoen with the title The Tragedy of Khamlet, Son of the Emperor of Qo'nos (2001), and also to a Klingon version of Hamlet's famous soliloquy on YouTube.

Furthermore, there are references to Shakespeare in various popular films, such as John McTiernan's Last Action Hero (1993), where a schoolboy who has to watch Olivier's Hamlet from 1948 imagines Arnold Schwarzenegger playing the main character (Otto 2014, 505). Another recent reference to Shakespeare's plays can be found in the 3D-animated comedy Gnomeo and Juliet (2011), where the famous tragedy Romeo and Juliet is adapted around a dooryard. This production is not only part of global popular entertainment; it is at the same time a British, Canadian and American co-production and therefore an economic as well as artistic form of transatlantic collaboration. Shakespeare is a global player in popular culture, so it is not surprising that even the international series The Simpsons offers a very loose version of Hamlet in the fourteenth episode of the thirteenth season. The title of the episode "Tales of the Public Domain” refers to Shakespeare as part of circulating cultural knowledge, clearly appropriable within various genres and media. Furthermore, FX Network broadcasted another very loose allusion to Hamlet in their series Sons of Anarchy (2008), which takes a criminal motorcycle gang in California as the starting point to reflect on the agency of a 'Hamletesque' intergenerational conflict. These examples show Shakespeare as a rich provider of plot structure that can be appropriated within various genres and media. However, the multiple references on the World Wide Web and various communication platforms confirm that Shakespeare offers a certain framework for thinking, and thus a common platform to compare cultural phenomena.

The aim of this chapter has been to open a broad perspective on various phenomena which could be described as 'transatlantic Shakespeare.' In this sense it has offered a condensed overview of central aspects of cultural circulation processes. Focussing on conditions and effects of these processes, this chapter has discussed different concepts such as adaptation, cultural ownership and rehumanisation. Even though these concepts play a crucial part in understanding the appropriation of Shakespeare within North American culture, the chapter has not investigated them further. These cultural appropriations have been understood as premises in order to 
investigate the multiple aspects of cultural circulation and bring various phenomena into a comparative perspective. Therefore, the chapter has offered a restricted consideration of transatlantic circulation processes, which highlight Shakespeare as a global player.

\section{Bibliography}

\subsection{Works Cited}

Ailles, Jennifer. "Adapting the Bard: A Virtual Guide." CTR: Canadian Theatre Review 111 (Summer 2002): 28-32.

Atwood, Margaret. "Gertrude Talks Back." Good Bones. London: Bloomsbury, 1992.15-18.

Brydon, Diana, and Irena Makaryk. Shakespeare in Canada: A world Elsewhere? Toronto: University of Toronto Press, 2002.

Buchanan, Judith. Shakespeare on Silent Film: An Excellent Dumb Discourse. Cambridge: Cambridge University Press, 2009.

Burnett, Mark T. "Figuring the Global/Historical in Filmic Shakespearean Tragedy.” A Concise Companion to Shakespeare on Screen. Ed. Diana E. Henderson. Malden: Blackwell Publishing, 2006. 133-154.

Burnett, Mark T. Filming Shakespeare in the Global Marketplace. Basingstoke: Palgrave Macmillan, 2012.

Cartelli, Thomas P. “'The Killing Stops Here': Unmaking the Myths of Troy in the Wooster Group/RSC Troilus\&Cressida (2012)." Shakespeare Quarterly 64.2 (2013): 133-143.

Emerson, Ralph W. "Shakespeare; or, the Poet." Shakespeare in America: An Anthology from the Revolution to Now. Ed. James Shapiro. New York: Literary Classics of the United States, 2014. 105-123.

Engler, Bernd. "American Literary Nationalism and the Cultural Politics of 'De-Nationalizing' Shakespeare." ZAA 51.4 (2003): 400-420.

Fischlin, Daniel. “Canada." Hamlet Handbuch: Stoffe, Aneignungen, Deutungen. Ed. Peter W. Marx. Stuttgart and Weimar: Metzler, 2014. 353-358.

Fowler, Benjamin. "Culture Clash: What the Wooster Group revealed about the RSC (and British theatre hegemony) in Troilus \& Cressida." Shakespeare Bulletin 32.2 (2014): 207-233.

Garber, Marjorie. Shakespeare and Modern Culture. New York: Pantheon Books, 2008.

Greenblatt, Stephen, ed. Cultural Mobility: a Manifesto. Cambridge: Cambridge University Press, 2010.

Greenhalgh, Susanne. "Troilus and Cressida performed by Wooster Group (review)." Shakespeare Bulletin 31.4 (Winter 2014): 749-754.

Hill, Anthony D., with Douglas Q. Barnett, eds. Historical Dictionary of African American Theater. Lanham, MD: Scarecrow Press, 2009.

Hill, Errol. Shakespeare in Sable: A History of Black Shakespearean Actors. Amherst: University of Massachusetts Press, 1984.

Hornback, Robert. "Black Shakespeareans vs. Minstrel Burlesques: 'Proper’ English, Racist Blackface Dialect, and the Contest for Representing 'Blackness', 1821-1844.” Shakespeare Studies 38 (2010): 125-160.

Huang, Alexa. "Global Shakespeare as Methodology." Shakespeare: Journal of the British Shakespeare Association 9.3 (2013): 273-290. 
Knowles, Ric. Shakespeare and Canada: Essays on Production, Translation, and Adaptation.

Brussels: P. I. E. Peter Lang, $2004 a$.

Knowles, Ric. Reading the Material Theatre. Cambridge: Cambridge University Press, 2004b. Knutson, Susan, ed. Canadian Shakespeare. Toronto: Playwrights Canada Press, 2010.

Lanier, Douglas. Shakespeare and Modern Popular Culture. Oxford: Oxford University Press, 2002. Laurence, Margaret. The Diviners. New York: Knopf, 1974.

LeCompte, Elizabeth, and Kate Valk with Maria Shevtsova. "A Conversation on The Wooster Group's Troilus and Cressida with the RSC." New Theatre Quarterly 29.3 (August 2013): 233-246.

Lenhardt, Allison K. "The American Shakespeare Center's Actors' Renaissance Season:

Appropriating Early Modern Performance Documents and Practices." Shakespeare Bulletin 30.4 (Winter 2012): 449-467.

Lindfors, Bernth. “Ira Aldridge at Covent Garden, April 1933." Theatre Notebook 61.3 (2007): 144-169.

Mancewicz, Aneta. Intermedial Shakespeare on European Stages. Basingstoke: Palgrave Macmillan, 2014.

McParland, Robert. Mark Twain's Audiences: A Critical Analysis of Reader Responses to the Writings of Mark Twain. Lanham, MD: Lexington Books, 2014.

Otto, Ulf. "Zwischen Fernsehserie, Vorabendprogramm und Computerspiel." Hamlet Handbuch: Stoffe, Aneignungen, Deutungen. Ed. Peter W. Marx. Stuttgart and Weimar: Metzler, 2014. 504-507.

Paul, Gavin. "Border Wars: Shakespeare, Robert Lepage, and the Production of National Sentiment." Upstart Crow: A Shakespeare Journal 26 (2007): 45-60.

Rippl, Gabriele. "Hamlet in nordamerikanischen Romanen und Kurzgeschichten." Hamlet Handbuch: Stoffe, Aneignungen, Deutungen. Ed. Peter W. Marx. Stuttgart and Weimar: Metzler, 2014. 441-450.

Sturgess, Kim C. Shakespeare and the American Nation. Cambridge: Cambridge University Press, 2004.

Taylor, Neil. "National and Racial Stereotypes in Shakespeare Films." The Cambridge Companion to Shakespeare on Film. Ed. Russell Jackson. Cambridge: Cambridge University Press, 2000. 261-273.

Teague, Fran[ces]. Shakespeare and the American Popular Stage. Cambridge: Cambridge University Press, 2006.

Teague, Fran[ces]. "Shakespeare and America." The Oxford Handbook of Shakespeare. Ed. Arthur F. Kinney. Oxford: Oxford University Press, 2012. 719-734.

Tocqueville, Alexis de. Democracy in America: Part the Second. Trans. Henry Reeve. New York: J. \& H. G. Lanley, 1840.

Twain, Mark. Huckleberry Finn. Auckland: Floating Press, 1884.

Vaughan, Alden T., and Virginia M. Vaughan. Shakespeare in America. Oxford: Oxford University Press, 2012.

Walker, Elsie. "Getting Back to Shakespeare: Whose Film Is it Anyway?" A Concise Companion to Shakespeare on Screen. Ed. Diana E. Henderson. Malden, MA: Blackwell Publishing, 2006. 8-30.

Winfield, Jess. My Name Is Will: A Novel of Sex, Drugs and Shakespeare. New York: Twelve, 2008. Wyman, Lillie Buffum C. Gertrude of Denmark: An Interpretive Romance. Boston: Marshall Jones Company, 1924.

Young, Harvie. Theater \& Race. Basingstoke: Palgrave Macmillan, 2013. 


\subsection{Further Reading}

Bristol, Michael D. Shakespeare's America and America's Shakespeare. London and New York: Routledge, 1990.

Gayley, Charles M. Shakespeare and the Founders of Liberty in America. New York: The Macmillan Company, 1917.

Lindfors, Bernth. Ira Aldridge: Performing Shakespeare in Europe, 1852-1855. Rochester, NY: University of Rochester Press, 2013.

Shapiro, James, ed. Shakespeare in America: An Anthology from the Revolution to Now. New York: Literary Classics of the United States, 2014.

Thompson, Ayanna. Passing Strange: Shakespeare, Race and Contemporary America. Oxford and New York: Oxford University Press, 2011.

\subsection{Films}

A Midsummer Night's Dream. Dir. Max Reinhardt. Warner Bros.,1935.

Hamlet. Dir. Kenneth Branagh. Castle Rock Entertainment, 1996.

Hamlet. Dir. Lawrence Olivier. Two Cities Films, 1948.

Hamlet. Dir. Michael Almereyda. double A Films, 2000.

Julius Caesar. Dir. Joseph L. Mankiewicz. MGM, 1953.

Last Action Hero. Dir. John McTiernan. Columbia Pictures Corp., 1993.

Looking for Richard. Dir. Al Pacino. Chal Productions et al., 1996.

Love's Labour's Lost. Dir. Kenneth Branagh. Pathé Pictures international, 2000.

“O.” Dir. Tim Blake Nelson. Chickie the Cop et al., 2001.

Star Trek VI: The Undiscovered Country. Dir. Nicholas Meyer. Paramount Pictures, 1991.

The Merchant of Venice. Dir. Michael Radford. Avenue Pictures Productions et al., 2004.

William Shakespeare's Romeo+Juliet. Dir. Baz Luhrman. Twentieth Century Fox et al., 1996.

10 Things I hate about you! Dir. Gil Junger. Touchstone Pictures, 1999. 